\title{
Estimation of the traction power of agricultural tractors from dynamometric tests
}

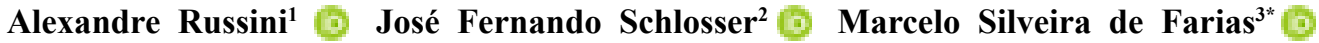

\footnotetext{
'Universidade Federal do Pampa (UNIPAMPA), Campus Itaqui, Itaqui, RS, Brasil.

${ }^{2}$ Departamento de Engenharia Rural (DER), Centro de Ciências Rurais (CCR), Universidade Federal de Santa Maria (UFSM), Santa Maria, RS, Brasil.

${ }^{3}$ Departamento de Ciências Agronômicas e Ambientais (DCAA), Universidade Federal de Santa Maria (UFSM), 98400-000, Campus Frederico Westphalen, Frederico Westphalen, RS, Brasil. E-mail: silveira_farias@hotmail.com. .Corresponding author.
}

\begin{abstract}
The objective of this research was to predict, from dynamometric tests, the traction performance of agricultural tractors, without the need to employ the standard official tests carried out on concrete tracks. The evaluations were conducted at the experimental area of the Universidade Federal de Santa Maria, where an instrumented agricultural tractor was subjected to dynamic field traction tests and static tests in the laboratory, using an eddy currents dynamometer. It can be verified through the correlation analysis between the values obtained and the estimated values that, based on the prediction equations, a high correlation $\left(r^{2}=0.99\right)$ was obtained between the power observed in the field and the estimated power obtained using dynamometric tests. Based on the analysis of the results obtained in this study, it can be stated that the traction performance of an agricultural tractor can be estimated from dynamometric tests. We concluded that the dynamic field tests can be replaced by static tests carried out in laboratories, which are generally less expensive.
\end{abstract}

Key words: traction test, dynamometry, performance.

Estimativa da potência em tração de tratores agrícolas a partir de testes dinamométricos

RESUMO: $O$ objetivo deste trabalho foi prever, a partir de testes dinamométricos, o desempenho em tração de tratores agrícolas, sem a necessidade de recorrer aos ensaios oficiais normalizados realizados em pistas de concreto. As avaliações foram conduzidas em área experimental, da Universidade Federal de Santa Maria, onde um trator agrícola instrumentado foi submetido a testes dinâmicos de tração, em superficie de campo e testes estáticos, em laboratório, utilizando-se freio dinamométrico elétrico, de correntes de Foucault. Pode-se verificar por meio da análise de correlação entre os valores obtidos e os valores estimados que, com base nas equações de predição, obteve-se alta correlação $\left(r^{2}=0,99\right)$ entre a potência observada em campo e a potência estimada, a partir dos testes dinamométricos. Com base nas análises dos resultados obtidos neste estudo, pode-se afirmar que o desempenho em tração de um trator agrícola pode ser estimado a partir de testes dinamométricos. Conclui-se que, os ensaios dinâmicos em campo podem ser substituídos por ensaios estáticos, realizados em laboratórios, que em geral são menos onerosos.

Palavras-chave: ensaio de tração, dinamometria, desempenho.

\section{INTRODUCTION}

The power and fuel consumption of agricultural tractors can be obtained at the power take-off (PTO) by using a brake dynamometer. In turn, the tractive performance of a tractor is obtained by performing a drawbar test, in which the tractor pulls a given load across a concrete track (SILVEIRA \& SIERRA., 2010). In this regard, according to ZOZ \& GRISSO (2003), the main factor to be observed for tractors is the drawbar performance, which, according to MONTEIRO et al. (2011), is a parameter used for comparing and evaluating agricultural tractors.

According to MONTEIRO et al. (2013), the tractor test on agricultural soil is one way of obtaining information about a tractor, especially about its tractive performance. In addition, the drawbar performance can be used to evaluate and/or compare tractors. However, the drawbar performance is affected by the conditions of the work surface, the gear ratio, and the ratio of the tractor's mass to its power.

Poor drawbar performance is caused by factors such as the soil type, mass distribution on 
wheel sets, wheel set characteristics, mass transfer during operation, and vegetation cover (GABRIEL FILHO et al., 2004). These interrelations perfectly explain why a tractor is unable to use the total power generated by the engine, at the drawbar. In most tractors, approximately $60 \%$ to $65 \%$ of the power generated by the engine is transformed, effectively, into tractive power (MÁRQUEZ, 2012).

The solution found by research institutions to obtain the tractive performance of agricultural tractors was to standardize the tests with the use of concrete tracks (OECD, 2014). The standardization enables the reproduction of tractive performance tests in different locations, always under the same conditions, which allows inferences and comparisons between different tractor brands and models to be made (MACMILLAN, 2002).

An efficient and low-cost alternative to obtain the tractive performance of agricultural tractors involves using dynamometric tests. These tests provide the characteristic curves of engine performance, i.e., curves of torque, power, and specific fuel consumption. The experimentally obtained dynamic coefficients and the scientifically known mathematical equations allow the estimation of the tractive power of an agricultural tractor in real field conditions, without using the traditional traction tests (MÁRQUEZ, 2012).

Hence, this study aimed to predict, by using dynamometric tests, the tractive performance of agricultural tractors, without the need for performing dynamic traction tests on tracks.

\section{MATERIALS AND METHODS}

\section{Research tractor}

The experiment involved the use of an MF 4297 tractor (Massey Ferguson, Canoas, Brazil) equipped with a four-stroke Diesel cycle engine (AGCO Power, 420 DS) with four cylinders and an engine displacement of $4400 \mathrm{~cm}^{3}$, and overfed by a turbocharger. According to the information provided by the manufacturer, the engine provides a maximum power of $88.5 \mathrm{~kW}(120 \mathrm{hp})$ and maximum torque of $460 \mathrm{~N} . \mathrm{m}$ under the ISO TR 14396 standard. The tractor was equipped with R1-type wheels, having a diagonal construction with the following dimensions: front 14.9-28 and rear 23.1-30, where the dynamic radius of the rear wheel set was $0.838 \mathrm{~m}$, with activated mechanic front wheel drive (MFWD).

The tractor's mass was $5,720 \mathrm{~kg}$, which was obtained by weighing it on a scale comprising four individual platforms supported under the wheel sets, with a static distribution of $41 \%$ and $59 \%$ on the front and rear wheel sets, respectively. The mass/power ratio of $64.63 \mathrm{~kg} \mathrm{~kW}^{-1}$ was established according to the manufacturer's recommendation; according to Schlosser et al. (2005), the ideal mass/ power ratio for heavy agricultural operations, i.e., operations that require greater traction force should be approximately $60 \mathrm{~kg} \mathrm{~kW}^{-1}$.

\section{Experimental test in laboratory}

The determination of the values of torque and effective engine power involved the use of MWD electric dynamometric brakes (NL 480, Argentina), with a brake capacity up to $552 \mathrm{~kW}$ (750hp) of continuous maximum power, and an Oval Flowmate flow meter (OVAL M-III, LSF 41L) to quantify the volume of fuel consumed. This equipment has an automatic data acquisition system, wherein data can be viewed and interpreted with the Accudyno ${ }^{\circledR}$ software.

To perform this test, the loads were applied using a potentiometer, requiring only the input of information about the identification of the test tractor and the transmission ratio of the engine speed and the PTO. The atmospheric pressure and air temperature were obtained using the atmospheric centerpiece of the brake dynamometer and were used to calculate the correction factor, which was performed automatically by the software.

The engine performance curves were determined on the basis of the NBR ISO 1585 (1996) standard and are shown in figure 1. Values of the torque and power at each working speed were used for the mathematical estimation of the tractive power, which were corrected considering the transmission efficiency of $90 \%$. This efficiency was calculated as a function of the difference between the engine power and torque, informed by the manufacturer in the official test, and the values obtained in the present study from the test at the PTO.

\section{Test method and procedure}

The methodology involved the identification and quantification of the factors that caused power losses, from the engine to the tractor drawbar. The estimation of the tractive power included the use of data such as the tractor's mass, engine torque and speed, transmission efficiency, transmission ratio, dynamic radius of wheels, coefficient of rolling, and slip resistance of the driving wheels.

Mathematical estimation of the tractive power was performed on Microsoft Excel ${ }^{\circledR}$, version 2016, where the spreadsheets were fed with the reference parameters that directly influence the tractive performance. Therefore, it was possible 


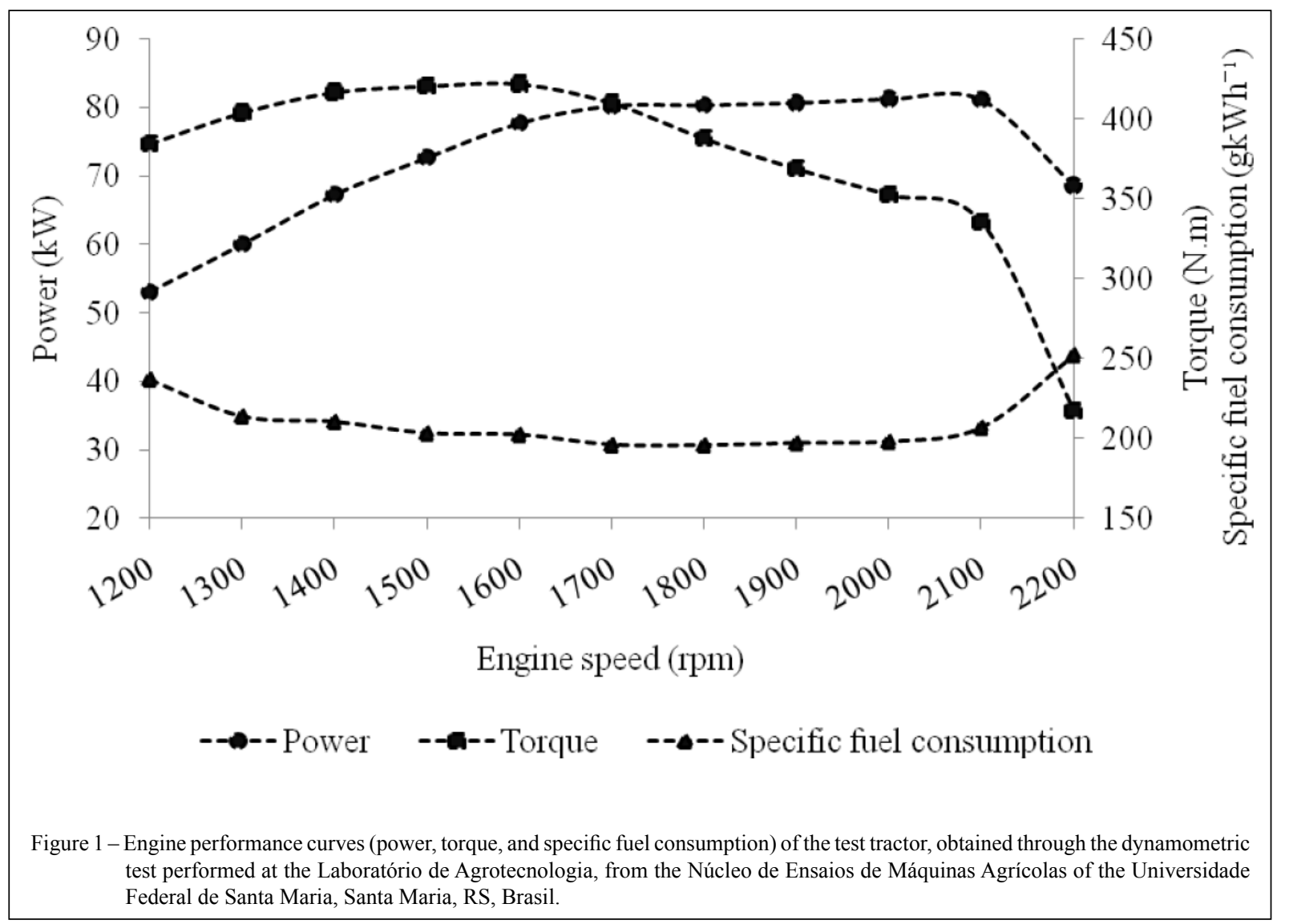

to calculate the behavior of the evaluated tractor in different situations using the characteristic curves of engine performance, which were obtained by performing dynamometric tests without the need to conduct tests on a concrete track.

Equation 1, which is derived from a dynamic analysis of the equilibrium of forces, described by MÁRQUEZ (2012), was used to obtain the drawbar power, which is directly influenced by the product of the traction force and the real travel speed.

$\mathrm{NB}=\mathrm{Q} \times \mathrm{v}=[(\mathrm{Ft}-\mathrm{RTk})] \times[\mathrm{vt} \times(1-\delta)]=[(\mathrm{Mm} \times \eta \mathrm{t}$ $\times$ it $/$ rdin $)-\mathrm{RTk}] \times[(2 \times \pi \times \operatorname{rdin} \times \mathrm{n} /$ it $) \times(1-\delta)](1)$

Where: $\mathrm{NB}=$ drawbar power $(\mathrm{kW}) ; \mathrm{Q}=$ traction force $(\mathrm{daN}) ; \mathrm{v}=$ real travel speed $\left(\mathrm{km} \mathrm{h}^{-1}\right) ; \mathrm{Ft}=$ tangential force of the driving wheel set $(\mathrm{daN})$; RTk = rolling resistance moment $(\mathrm{daN}) ; \mathrm{vt}=$ theoretical travel speed $\left(\mathrm{km} \mathrm{h}^{-1}\right) ; \delta=$ drive wheel slip (decimal); $\mathrm{Mm}=$ engine torque at the flywheel (daN.m); $\eta \mathrm{t}=$ transmission efficiency (decimal); it = ratio of transmission between engine and driving wheels (dimensionless); rdin = dynamic radius of driving wheels $(\mathrm{m}) ; \pi=$ constant (3.141592); and $\mathrm{n}=$ engine speed (rpm).
The transmission ratio was changed for each work gear, resulting in the tractive power for each selected gear, which maintained the constant torque and engine speed obtained in the dynamometric test. Equation 1 does not present the dynamic traction coefficient, which was obtained using the ratio between the traction force and the tractor's adherent mass. Nevertheless, dynamic traction coefficient value was experimentally obtained on the field and was used to correct the estimated values of traction power, considering the tractor's mass.

\section{Experimental field test}

Tests to determine the tractor's tractive field performance were conducted in the experimental area at the Universidade Federal de Santa Maria, Santa Maria, RS, Brasil, under a consolidated direct plantation system, with dystrophic Red Acrisol soil, slightly waved and cultivated with black oat (Avena Strigosa), for soil coverage.

To determine the tractive performance, the electronic instrumentation (Figure 2) developed 
by RUSSINI (2009) was used. This instrumentation contains a data logger (Campbell, CR 1000) to store the output data from the sensors placed in the tractor. The acquisition interval was 2 s. Fuel consumption was determined with the same flow meter that was used in the previously described dynamometric tests. The travel speed was obtained using GPS signal receptor (Trimble, AG 150), wherein the GPS delay was corrected by programming the data logger. Traction force was determined by load cell (Alfa, 10T), with $100 \mathrm{kN}$ capacity and properly gauged with a precision of $0.01 \mathrm{kN}$. Finally, the driving wheel slip was determined through inductive sensors fixed on metal supports on the outer part of the wheel rims, which indicate the rate of the passage of the 32 teeth of a teeth wheel by the sensor, thus indicating its rotation and speed.

To determine the traction force of the tractor, four work gears were used (T1: $2^{\text {nd }}$ low reduced, T2: $2^{\text {nd }}$ high reduced, T3: $3^{\text {rd }}$ low reduced, and T4: $3^{\text {rd }}$ high reduced), which corresponded, respectively, to the following transmission ratios: 169.35, 128.58, 100.63, and 77.15. Transmission ratios for the evaluated work gears were determined by suspending the rear wheel sets of the tractor, with activated differential lock, establishing the constant engine speed of 2,200rpm. Using a digital tachometer, the rotations of the center of the axis at the output of the last reduction were read, where the transmission ratio was calculated with the ratio of the engine speed and the value obtained at the axis.

The tractor pulled, under a constant load, the brake tractor with greater power and mass in relation to the first tractor by selecting a gear that provided a lower travel speed with activated differential lock. The distance covered in each part was $60 \mathrm{~m}$, with no driving wheel slip in the brake tractor. At each part, the rolling resistance was determined by pulling the test tractor with the brake tractor, and adopting the mean value of three observations. Values were obtained by the reading of the load cell, but repositioned in front of the test tractor.

Once the traction power data obtained in the field experiment were organized in tables, they were compared with the values estimated by equation 1 , where the interrelation between the values obtained in the dynamometric test, with the transmission ratio obtained for the selected gear considering the dynamic traction coefficient, determining the final value for the estimation of the traction power.

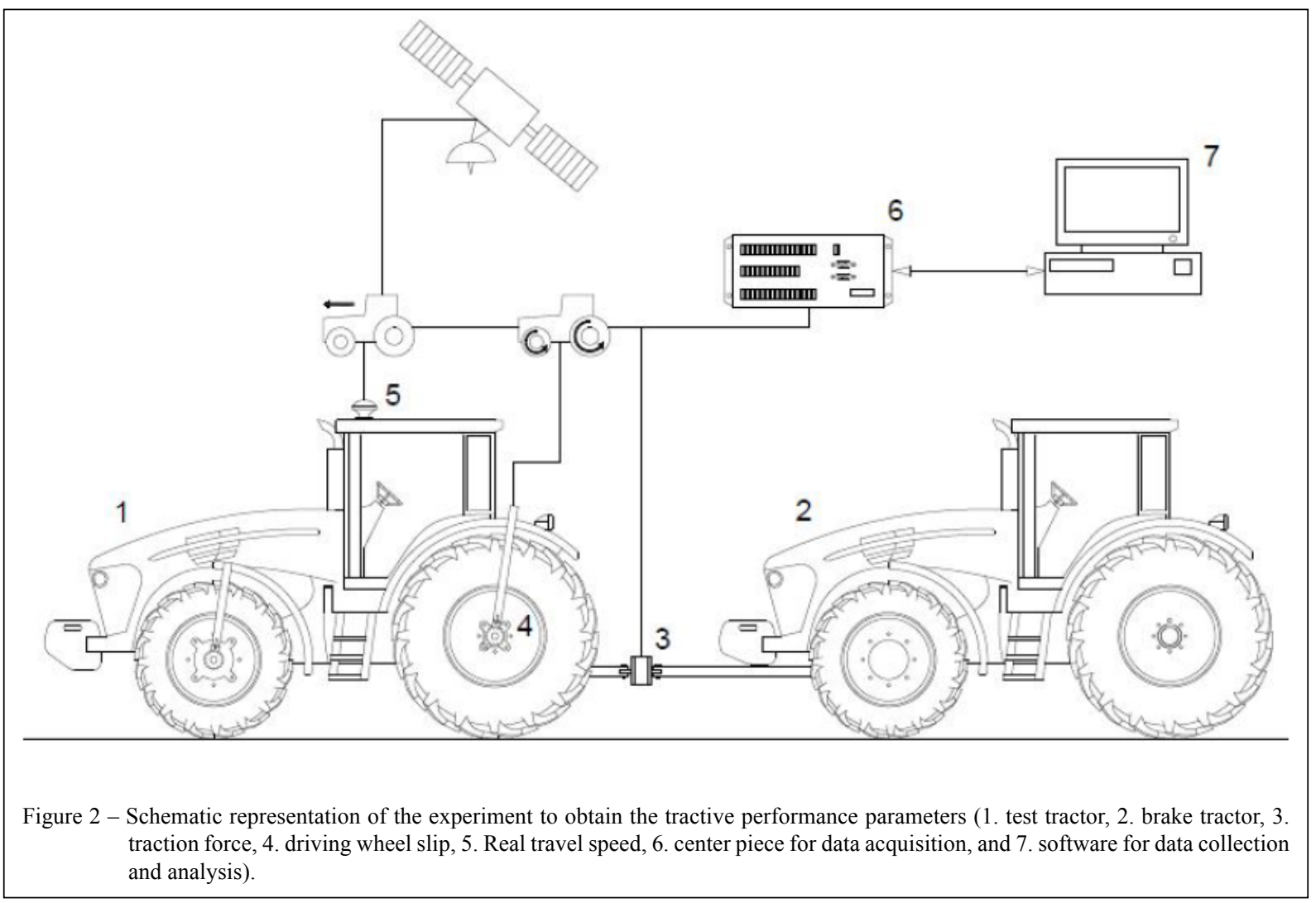

Ciência Rural, v.48, n.4, 2018. 


\section{Experimental and statistical procedures}

For statistical analysis, an experiment with randomized block experimental design was considered, where each treatment consisted of five repetitions. Then, the response variables (traction force, dynamic traction coefficient, real travel speed, slip, and drawbar power) were subjected to the analysis of variance (ANOVA) and Tukey's test of comparison of means at $5 \%$ significance level by using the Sisvar software, version 5.3 (FERREIRA, 2011).

Once the data set was confirmed for normality (Lilliefors test), the Pearson correlation analysis was performed to compare the results obtained in the field with those estimated using equation 1.

\section{RESULTS AND DISCUSSION}

The traction force values at the work gears are presented in table 1. Treatments T3 and T4 did not present differences; however, there was significant variation for the gear used in treatment $\mathrm{T} 1$, considering that to determine this parameter, the applied load was constant in all treatments.

This difference may be attributed to the high torque values at the driving wheels for this work gear in relation to the tractor's mass, which considerably reduces the dynamic traction coefficient, i.e., the traction force to the adherent mass ratio. Furthermore, the low value of the traction force in treatment $\mathrm{T} 1$ (Table 1) may have been caused by the increase in the driving wheel slip, which could be justified by the high critical speed (minimum travel speed of the tractor to use power produced by the engine in relation to its mass), given that in this treatment the speed was $6 \mathrm{~km}$ $\mathrm{h}^{-1}$, which was greater than that in other treatments.

This study did not considered travel speeds greater than the critical speed, because they are not appropriate for most agricultural operations performed in the field, which demand great traction effort and require the use of ballasting, which would exceed the maximum established limit according to the manufacturer.

A similar behavior was observed by GABRIEL FILHO et al. (2010) in relation to the drawbar power; they used an agricultural tractor with a power of $88 \mathrm{~kW}$ and travel speed similar to that used in treatment $\mathrm{T} 1$ in this experiment over a surface covered by culture remains, with no mobilization of soil, at the speed of $3.95 \mathrm{~km} \mathrm{~h}^{-1}$, and obtained the traction power of $27.79 \mathrm{~kW}$. In this experiment, the power generated in treatment T1 was $28.67 \mathrm{~kW}$ (Table 1) for a speed of $3.76 \mathrm{~km} \mathrm{~h}^{-1}$. According to NEUJAHR \& SCHLOSSER (2001), the slip values between $5 \%$ and $20 \%$ promoted the highest tractive efficiency.

The increase in slip in the driving wheels caused the decrease in the real travel speed and consequently, in the drawbar power, thereby obtaining the smallest value $(28.67 \mathrm{~kW})$, which efficiently transformed the engine power into traction power of $32 \%$. However, for the other three evaluated work gears, the mean efficiency was $55.60 \%$, a result similar to that obtained by MÁRQUEZ (2012) for a similar surface condition with a slip of approximately $8 \%$ to $13 \%$.

This behavior could be explained, because, as the travel speed increases, the torque produced in the driving wheels decreases and consequently, so does the slip, thereby increasing the traction force to a certain limit, reaching the critical speed. The mean rolling resistance value obtained in the field was $4.70 \mathrm{kN}$ (483kgf), which represents $8.40 \%(\mathrm{k}=0.08)$ of the total mass of the tractor. This value is within the range of rolling resistance predicted by LINARES et al. (2006) and MÁRQUEZ (2012), which is from 6 to $10 \%$.

The comparison using the analysis of correlation between the field results and those estimated with equation 1 is presented in table 2 . According to this analysis, there was no variation between the power observed in the field and the

Table 1 - Mean values of tractive performance parameters, obtained in field experiments.

\begin{tabular}{|c|c|c|c|c|c|}
\hline Treatments & Traction force $(\mathrm{kN})^{*}$ & Traction coeff & Travel speed $\left(\mathrm{km} \mathrm{h}^{-1}\right)$ & Slip (\%) & Drawbar power $(\mathrm{kW})$ \\
\hline $\mathrm{T} 1$ & $27.38^{\mathrm{a}}$ & $0.49^{\mathrm{a}}$ & $3.76^{\mathrm{a}}$ & $17.58^{\mathrm{a}}$ & $28.67^{\mathrm{a}}$ \\
\hline $\mathrm{T} 2$ & $38.73^{\mathrm{b}}$ & $0.69^{\mathrm{b}}$ & $4.34^{\mathrm{b}}$ & $14.94^{b}$ & $46.75^{b}$ \\
\hline $\mathrm{T} 3$ & $40.87^{\mathrm{c}}$ & $0.73^{b}$ & $4.47^{\mathrm{b}}$ & $14.79^{\mathrm{bc}}$ & $50.81^{\mathrm{c}}$ \\
\hline $\mathrm{T} 4$ & $40.47^{\mathrm{c}}$ & $0.72^{\mathrm{b}}$ & $5.52^{\mathrm{c}}$ & $13.22^{\mathrm{c}}$ & $62.08^{\mathrm{d}}$ \\
\hline Mean & 36.85 & 0.66 & 4.52 & 15.13 & 47.08 \\
\hline CV $(\%)$ & 5.79 & 5.92 & 2.09 & 6.73 & 6.04 \\
\hline
\end{tabular}

${ }^{*}$ Means followed by the same letters in the column do not differ between each other by Tukey test, considering the nominal value of significance at $5 \%(\rho \leq 0.05)$. 
Table 2 - Drawbar power, traction force and travel speed values obtained in field and estimated with mathematical equation 1.

\begin{tabular}{|c|c|c|c|c|c|c|}
\hline \multirow[t]{2}{*}{ Treatments } & \multicolumn{2}{|c|}{ Drawbar power $(\mathrm{kW})$} & \multicolumn{2}{|c|}{ Traction power $(\mathrm{kN})$} & \multicolumn{2}{|c|}{ Travel speed $\left(\mathrm{km} \mathrm{h}^{-1}\right)$} \\
\hline & Obtained & Estimated & Obtained & Estimated & Obtained & Estimated \\
\hline $\mathrm{T} 1$ & 28.67 & 24.80 & 27.38 & 27.37 & 3.76 & 3.19 \\
\hline $\mathrm{T} 2$ & 46.75 & 45.44 & 38.73 & 38.22 & 4.34 & 4.12 \\
\hline $\mathrm{T} 3$ & 50.81 & 52.19 & 40.87 & 40.83 & 4.47 & 4.51 \\
\hline $\mathrm{T} 4$ & 62.08 & 64.31 & 40.47 & 40.38 & 5.52 & 5.63 \\
\hline $\mathrm{r}^{2}$ & \multicolumn{2}{|c|}{0.997} & \multicolumn{2}{|c|}{0.994} & \multicolumn{2}{|c|}{0.985} \\
\hline
\end{tabular}

estimated power. Analyzing the results (Table 2), there were high correlation values, with a difference smaller than $0.1 \%$.

The equation of the force equilibrium dynamic analysis does not consider the dynamic traction coefficient; however, for the estimations performed, this parameter was used, thus justifying a correlation coefficient greater than $90 \%$ for the conditions of the experiment. Additionally, the large number of data collected in the field should be considered, given that the electronic system collected them every $2 \mathrm{~s}$, guaranteeing better representativeness during the experiment.

\section{CONCLUSION}

The tractive performance of an agricultural tractor in the field could be estimated quickly and with high accuracy by using dynamometric tests instead of the traditional dynamic traction tests, which are considered difficult to perform and require specific instrumentation, thus making them time-consuming and onerous.

This simulation can be employed by manufacturers and users of agricultural machinery to facilitate project development; selection and design of machinery. Further studies are required to evaluate whether the results are valid for all tractors or whether they are specific to the brand and model used in this experiment.

\section{ACKNOWLEDGEMENTS}

The authors are grateful to the Conselho Nacional de Desenvolvimento Científico e Tecnológico $(\mathrm{CNPq})$ for research productivity scholarship of the second author.

\section{REFERENCES}

ABNT NBR ISO 1585. Veículos rodoviários - Código de ensaio de motores - Potência líquida efetiva, Rio de Janeiro, p.9, 1996.
FERREIRA, D.F. Sisvar: a computer statistical analysis system. Ciência e Agrotecnologia, v.35, n.6, p.1039-1042, Nov./Dez. 2011. Available from: <http://www.scielo.br/pdf/cagro/v35n6/ a01v35n6.pdf>. Accessed: May 17, 2017. doi: 10.1590/S141370542011000600001 .

GABRIEL FILHO, A. et al. Tractor performance in soil with different types of plants covering. Engenharia Agrícola, v.24, n.3, p.781-789, Set./Dez. 2004. Available from: <http://www.scielo. br/pdf/eagri/v24n3/a32v24n3.pdf > . Accessed: Feb. 11, 2017. doi: 10.1590/S0100-69162004000300032.

GABRIEL FILHO, A. et al. Performance of agricultural tractor on three defferent soil surfaces and four forward speeds. Revista Brasileira de Engenharia Agrícola e Ambiental, v.14, n.3, p.333-339, 2010. Available from: <http://www.scielo.br/pdf/rbeaa/ v14n3/v14n03a15.pdf $>$. Accessed: Mar. 12, 2017. doi: 10.1590/ S0100-69162011000300015.

LINARES, P.; CATALÁN, H.; MÉNDEZ, V. Teoría de la tracción de tractores agrícolas. Madrid: Escuela Técnica Superior de Ingenieros Agrónomos da Universidad Politécnica de Madrid, p. 215,2006

MACMILLAN, R.H. The Mechanics of Tractor - Implement Performance: Theory and Worked Examples. Melbourne, p.165, 2002.

MÁRQUEZ, L. Tractores Agrícolas: Tecnología y utilización. España: B\&H Grupo Editorial, p.844, 2012.

MONTEIRO, L.A. et al. Performance of an agricultural tractor equipped with radial and bias ply tires on three levels of liquid ballast. Engenharia Agrícola, v.31, n.3, p.551-560, Mai./Jun. 2011. Available from: <http://www.scielo.br/pdf/eagri/v31n3/ a15v31n3.pdf $>$. Accessed: Jan. 8, 2017. doi: 10.1590/S010069162011000300015.

MONTEIRO, L.A. et al. Tractor drawbar efficiency at different weight and power ratios. Revista Ciência Agronômica, v.44, n.1, p.70-75, Jan./Mar. 2013. Available from: <http://www.scielo. br/pdf/rca/v44n1/a09v44n1.pdf $>$. Accessed: Dec. 10, 2016. doi: 10.1590/S1806-66902013000100009.

NEUJAHR, E.B.; SCHLOSSER, J.F. Performance on traction of radial and bias agricultural tires. Engenharia Agrícola, v.21, n.2, p.180-189, Mai. 2001. Available from: <http:// www.ufrrj.br/institutos/it/deng/varella/Downloads/IT154_ motores_e_tratores/Literatura/patinagem_1.pdf $>$. Accessed: Dec. 10,2016 . 
OECD. Organization for Economic Cooperation and Development. CODE 2: Standard code for the official testing of agricultural and forestry tractor performance. Paris, p.104, 2014.

RUSSINI, A. Projeto, construção e teste de instrumentação eletrônica para avaliação do desempenho de tratores agrícolas, 142f, 2009. Dissertação (Mestrado em Engenharia Agrícola) Universidade Federal de Santa Maria, Santa Maria, RS.

SCHLOSSER, J.F. et al. Comparative analysis of the specific weight and its effects on the selection and use of the Brazilian wheeled tractors.
Ciência Rural, v.35, n.1, p.92-97, 2005. Available from: <http://www. scielo.br/pdf/cr/v35n1/a14v35n1.pdf>. Accessed: Oct. 31 , 2017.

SILVEIRA, G.M; SIERRA, J.G. Energy efficiency of Brazilian agricultural tractors. Revista Brasileira de Engenharia Agrícola e Ambiental, v.14, n.4, p.418-424, 2010. Available from: <http:// www.scielo.br/pdf/rbeaa/v14n4/v14n04a11.pdf $>$. Accessed: Dec. 11, 2016. doi: 10.1590/S1415-43662010000400011.

ZOZ, F.M.; GRISSO, R.D. Traction and tractor performance. Louisville: ASAE, p.46, 2003. 